\title{
ANALISA INFRASTRUKTUR TEKNOLOGI INFORMASI MENGGUNAKAN FRAMEWORK COBIT 4.1
}

\author{
Ngajiyanto ${ }^{1}$, Ema Utami ${ }^{2}$ \\ Sistem Informasi ${ }^{1}$ Magister Teknik Informatika ${ }^{2}$ \\ STMIK Dian Cipta Cendikia Kotabumi, ${ }^{1}$ Universitas AMIKOM Yogyakarta ${ }^{2}$ \\ Jl. Negara No.03 Candimas Kotabumi Lampung Utara \\ E-mail : ngajiy@gmail.com, emma@nrar.net
}

\begin{abstract}
ABSTRAK
STMIK Dian Cipta Cendikia kotabumi adalah salah satu perguruan tinggi yang dalam operasionalnya menggunakan teknologi informasi, seperti sistem informasi akademik, sistem informasi jurnal dan lainlain, namun di STMIK Dian Cipta Cendikia Kotabumi belum memiliki suatu indikator yang dapat menyatakan bahwa kinerja teknologi informasi telah sesuai dengan tujuan yang ingin dicapai. Maka perlu dilakukan analisis tata kelola teknologi informasi guna mengetahui apakah performa teknologi informasi sekarang telah sesuai dengan yang diharapkan oleh manajemen atau tidak.

Metode yang digunakan dalam penelitian ini adalah metode deskriptif analisis dengan pendekatan kuantitatif, yaitu penelitian yang kemudian diolah dan dianalisis untuk diambil kesimpulan, maka penelitian dengan metode deskriptif kuantitatif yaitu suatu bentuk penelitian yang berdasarkan data yang dikumpulkan selama penelitian secara sistematis mengenai fakta-fakta dan sifat-sifat dari obyek yang diteliti dengan menggabungkan hubungan antar variable yang terlibat didalamnya, kemudian diinterpretasikan berdasarkan teori-teori dan literatur- literatur yang bertujuan untuk memberikan gambaran yang cukup jelas atas masalah yang diteliti, dan data tersebut akan dihitung secara statistik.

Berdasarkan analisa tingkat kematangan maturity level pada domain DS11 didapatkan bahwa tingkat kematangan berada pada level 4-Defined level, untuk domain DS12 didapatkan bahwa tingkat kematangan berada pada level 4 - Defined leve, dan pada domain ME01 didapatkan bahwa tingkat kematangan berada pada Level: 4 - Defined level.
\end{abstract}

Kata kunci: Maturity, Data, Teknologi Informasi STMIK Dian Cipta Cendikia kotabumi adalah salah satu perguruan tinggi yang dalam operasionalnya menggunakan teknologi informasi, seperti sistem informasi akademik, sistem informasi jurnal dan lain-lain, namun di STMIK Dian Cipta Cendikia Kotabumi belum memiliki suatu indikator yang dapat menyatakan bahwa kinerja teknologi informasi telah sesuai dengan tujuan yang ingin dicapai. Maka perlu dilakukan analisis tata kelola teknologi informasi guna mengetahui apakah performa teknologi informasi sekarang telah sesuai dengan yang diharapkan oleh manajemen atau tidak.

Metode yang digunakan dalam penelitian ini adalah metode deskriptif analisis dengan pendekatan kuantitatif, yaitu penelitian yang kemudian diolah dan dianalisis untuk diambil kesimpulan, maka penelitian dengan metode deskriptif kuantitatif yaitu suatu bentuk penelitian yang berdasarkan data yang dikumpulkan selama penelitian secara sistematis mengenai fakta-fakta dan sifat-sifat dari obyek yang diteliti dengan menggabungkan hubungan antar variable yang terlibat didalamnya, kemudian diinterpretasikan berdasarkan teori-teori dan literatur- literatur yang bertujuan untuk memberikan gambaran yang cukup jelas atas masalah yang diteliti, dan data tersebut akan dihitung secara statistik.

Berdasarkan analisa tingkat kematangan maturity level pada domain DS11 didapatkan bahwa tingkat kematangan berada pada level 4-Defined level, untuk domain DS12 didapatkan bahwa tingkat kematangan berada pada level 4 - Defined leve, dan pada domain ME01 didapatkan bahwa tingkat kematangan berada pada Level: 4 - Defined level.

Kata kunci: Maturity, Data, Teknologi Informasi 


\begin{abstract}
s
STMIK Dian Cipta Cendikia Kotabumi is one of the tertiary institutions operating in information technology, such as academic information systems, journal information systems and others, but at STMIK Dian Cipta Cendikia Kotabumi does not yet have an indicator that can state that the performance of information technology is in accordance with goals to be achieved. Then it is necessary to analyze information technology governance to find out whether the performance of information technology is now as expected by management or not.

The method used in this research is descriptive analysis method with quantitative approach, that is research which is then processed and analyzed to draw conclusions, then research with quantitative descriptive method is a form of research based on data collected during research systematically about the facts and nature -the nature of the object under study by combining the relationships between the variables involved in it, then interpreted based on theories and literature that aims to provide a fairly clear picture of the problem under study, and the data will be calculated statistically.

Based on maturity level maturity level analysis in DS11 domain, it is found that maturity level is at level 4-Defined level, for DS12 domain it is found that maturity level is at level 4 - Defined leve, and at MEO1 domain it is found that maturity level is at Level: 4 - Defined level.
\end{abstract}

Keywords: Maturity, Data, Teknologi Informasi

\section{PENDAHULUAN}

Perguruan tinggi merupakan sebuah institusi yang memberikan pelayanan kepada masyarakat untuk menyiapkan Sumber Daya Manusia (SDM) masa depan yang bermutu dan berdaya guna sebagai salah satu tugas yang diembannya. Dalam prosesnya, perguruan tinggi membutuhkan sumber informasi yang mutakhir dan selalu terkini. Pengembangan implementasi teknologi informasi dan komunikasi di perguruan tinggi merupakan upaya yang sudah seharusnya dilakukan. Aktivitas utama dalam perguruan tinggi sesuai dengan fungsi utamanya yaitu sebagai penyelenggara pendidikan adalah layanan akademik. Dalam pelaksanaan layanan akademik ini perlu adanya penggunaan TI yang dapat mendukung tercapainya sasaran dari sistem informasi akademik dosen tersebut [3].

STMIK Dian Cipta Cendikia kotabumi adalah salah satu perguruan tinggi yang dalam operasionalnya menggunakan teknologi informasi, seperti sistem informasi akademik, sistem informasi jurnal dan lain-lain, namun di STMIK Dian Cipta Cendikia Kotabumi belum memiliki suatu indikator yang dapat menyatakan bahwa kinerja teknologi informasi telah sesuai dengan tujuan yang ingin dicapai. Maka perlu dilakukan analisis tata kelola teknologi informasi guna mengetahui apakah performa teknologi informasi sekarang telah sesuai dengan yang diharapkan oleh manajemen atau tidak [4].

Oleh karena itu, dengan dilakukannya analisis tata kelola teknologi informasi diharapkan perguruan tinggi dapat mengetahui kelemahan/kekurangan potensial dalam sistem informasi ataupun teknologi informasi seperti bagaimana menangani sistem informasi akademik mahasiswa dengan berbagai macam data yang masuk ke sistem dengan keterbatasan sumber daya manusia dan keterbatasan waktu yang dapat mengganggu kegiatan operasional perguruan tinggi [5].

Sehubungan dengan alasan tersebut, diperlukan adanya sebuah mekanisme audit terhadap pengelolaan teknologi informasi (IT governance). Secara umum kerangka kerja tata kelola TI serta pengendalian yang dibutuhkan untuk mencapainya disediakan oleh COBIT (Control Objective for Information and related Technology). COBIT merupakan suatu kerangka kerja atau panduan standar praktik manajemen teknologi informasi. Praktik-praktik tersebut akan membantu mengoptimalkan investasi teknologi informasi, memastikan penyampaian layanan dan menghasilkan pengukuran dalam menentukan saat dimana terjadi kesalahan [4].

COBIT muncul pertama kali pada tahun 1996 yaitu COBIT versi 1 yang menekankan pada audit, COBIT versi 2 pada tahun 1998 yang menekankan pada tahap pengendalian, COBIT versi 3 pada tahun 2000 yang berorientasi kepada manajemen, COBIT versi 4 pada bulan desember 2005 dan versi 4.1 pada bulan mei 2007 lebih mengarah pada tata kelola TI, dan terakhir COBIT versi 5 pada bulan juni 2012 yang menekankan tata kelola TI pada.[4]. Pada COBIT 4.1 lebih berorientasi pada proses 
sedangkan cobit 5 lebih berorientasi pada prnsip [7].

Penerapan sistem informasi pada organisasi menghabiskan biaya yang tidak sedikit, oleh karena itu proses audit yang bertujuan untuk mengevaluasi dan menghindari masalah sistem seperti kerusakan data, kehilangan data, serta penyalahgunaan sistem perlu dilakukan secara periodik. Penelitian dilakukan untuk mengukur tingkat kematangan TI STMIK DCC Kotabumi menggunakan Cobit 4.1 yang fokus pada domain DS, dan ME(Winalia, Winalia, Faiza Renaldi, and Asep Id Hadiana, 2017

Berdasarkan uraian diatas maka penulis mengambil judul "MENGGUNAKAN FRAMEWORK COBIT 4.1 dengan Studi Kasus: STMIK Dian Cipta Cendikia Kotabumi”.

\section{METODE PENELITIAN}

2.1 Metode Pengumpulan Data

Pengumpulan data merupakan kegiatan yang penting bagi kegiatan penelitian, karena pengumpulan data tersebut akan menentukan berhasil tidaknya suatu penelitian. Sehingga dalam pemilihan teknik pengumpulan data harus cermat. Teknik pengumpulan data yang digunakan dalam penelitian ini adalah:

1. Wawancara

Wawancara adalah teknik pengumpulan data dengan mengajukan pertanyaan langsung oleh pewawancara kepada responden, dan jawabanjawaban responden dicatat atau direkam (Hasan, 2002: 85). Sedangkan maksud dari wawancara menurut Lincon dan Guba (1985) dalam Basrowi dan Suwandi (2008: 127) ialah mengonstruksi perihal orang, kejadian, kegiatan, organisasi, perasaan, motivasi, tuntutan, dan kepedulian, merekonstruksi kebulatan-kebulatan harapan pada masa yang akan datang, memverifikasi, mengubah dan memperluas informasi dari orang lain. Wawancara dalam penelitian ini digunakan untuk mengetahui persepsi pemustaka tentang kinerja pustakawan.

\section{Observasi}

Observasi adalah teknik pengumpulan data dengan melakukan pengamatan langsung pada objek kajian. Menurut Hasan (2002: 86) Observasi ialah pemilihan, pengubahan, pencatatan, dan pengodean serangkaian perilaku dan suasana yang berkenaan dengan organisasi, sesuai dengan tujuan-tujuan empiris. Observasi yang di maksud dalam teknik pengumpulan data ini ialah observasi pra-penelitian, saat penelitian dan pasca-penelitian yang digunakan sebagai metode pembantu, dengan tujuan untuk mengamati bagaimana kinerja pustakawan pada layanan sirkulasi.

\section{Studi Pustaka \\ Menurut Martono (2011: 97) studi pustaka dilakukan untuk memperkaya pengetahuan mengenai berbagai konsep yang akan digunakan sebagai dasar atau pedoman dalam proses penelitian. Peneliti juga menggunakan studi pustaka dalam teknik pengumpulan data.}

\subsection{Metode Analis Data}

Disini akan mengemukakan dasar pemikiran dan langkah-langkah pemilihan control objective yang digunakan didalam pembentukan model tatakelola TI khususnya dari sisi DS (Delivery Support) dan ME (Monitoring Evaluation).

Penelitian ini menggunakan teknik analisis data secara deskriptif-kuantitatif. Desain deskriptifkuantitaif yang umum digunakan yaitu Disain Deskriptif Kuisioner, ini dilakukan dengan mengambil sampel dari populasi sebagai subyek penelitian. Hasil isian inilah yang akan mendeskripsikan tentang variabel yang diteliti. Disini ada 50 responden yang dipilih dari populasi yang akan mengisi pernyataan yang ada sebanyak 579 buah untuk kemudian dilakukan analisis data secara deskriptif-kuantitatif dari masing-masing variabel dan karakteristik sampel.

Analisa tingkat kematangan dilakukan untuk mengetahui tingkat kematangan tata kelola TI berdasarkan kondisi tatakelola TI institusi saat ini yang diperoleh melalui isian kuisioner sesuai dengan standarisasi yang ditetapkan oleh COBIT. Analisa tingkat kematangan dilakukan dengan mengolah hasil isian kuisioner maturity models pada responden. Perancangan kuesioner dilakukan dengan memberikan sejumlah pertanyaan untuk setiap level control objectives yang ada pada Domain DS dan ME.

\subsection{Alur Penelitian}

Dalam melakukan penelitian ini, dilakukan langkah - langkah evaluasi tata kelola teknolgi informasi mengunakan cobit 4.1 yang diilustrasikan seperti langka-langkah berikut yang disajikan seperti gambar dibawah. 


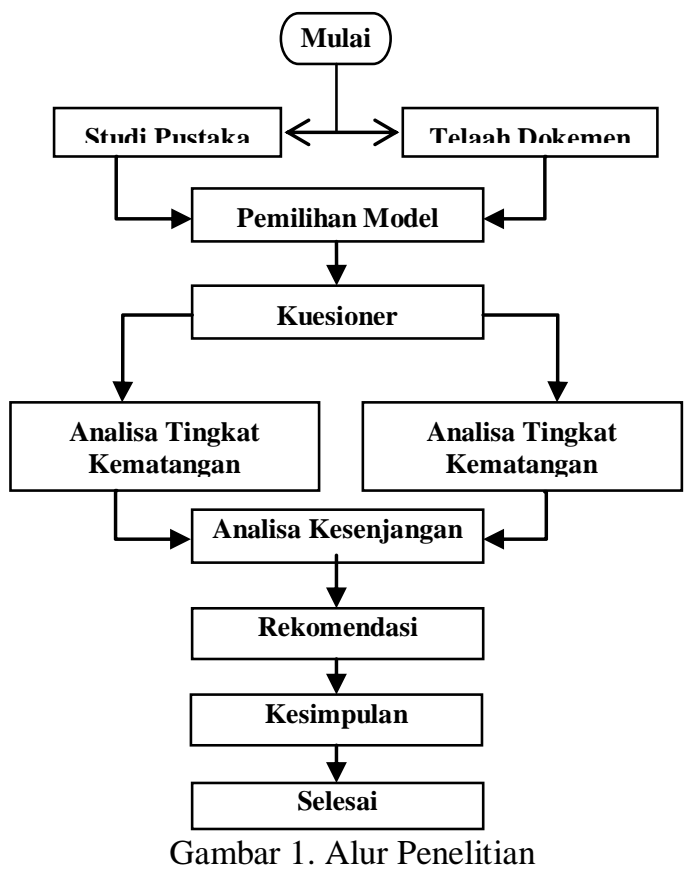

3.HASIL DAN PEMBAHASAN

4.1. Studi Pustaka dan Telaah dokumen 4.1.2 Dukungan penelitian sebelumnya Ditemukan bahwa dari 7 (Tujuh) penelitian sebelumnya yang telah dimuat dalam jurnal ilmiah banyak yang mendukung dalam penelitian ini, jurnal-jurnal tersebut yaitu:

1. Evaluasi tingkat kematangan teknologi informasi dengan menggunakan model maturity level cobit 4.1 (studi kasus pt. Bri cabang bangkinang), oleh mega wati dan fauzi amrullah, jurnal sains dan teknologi, 2014

2. Analisis tata kelola teknologi informasi ( it governance ) pada bidang akademik dengan cobit frame workstudi kasus pada universitas stikubank semarang, oleh agus prasetyo utomo dan novita mariana, jurnal teknologi informasi dinamik volume 16 , no.2, juli 2011

3. Pengukuran tata kelola infrastruktur teknologi informasi berdasarkan cobit frame work 4.1 (studi kasus universitas pembangunan nasional "veteran" jawa timur, oleh ronggo alit, djoko budiyanto, benyamin 1. Sinaga, jurnal scan vol x2015

4. Analisa tata kelola teknologi informasi menggunakan kerangka kerja cobit 4.1 pada fakultas teknologi undip, arini, adan fatchur rochim dan ike pertiwi windasari, jurnal teknologi dan sistem komputer, 2014
5. Penilaian tingkat kematangan strategic alignment bisnis dan ti menggunakan cobit 4.1 studi kasus universitas cyz, oleh agnes djohan dan marcel, seminar nasional sistem informasi indonesia, 2014

6. Penggunaan kerangka kerja cobit untuk menilai pengelolaan teknologi informasi dan tingkat pelayanan (studi kasus pada bmt " $x$ " yogyakarta), oleh jurnal teknologi informasi, sugeng winardi, vol. Vii nomor 19 maret 2012

7. The application for measuring the maturity level of information technology governance on indonesian government agencies using cobit 4.1 framework, oleh intelligent information management, 2014, 6, 12-19

Penelitian-penelitian sebelumnya yang mendukung penelitian ini adalah menyangkut cara penarikan atau penyusunan rekomendasi yang diturunkan dari setiap domain dengan tingkat kematangan yang rendah dijadikan sebagai saran perbaikan. Beberapa kelemahankelemahan dari penelitian sebelumnya dijadikan sebagai acuan untuk perbaikan dalam penelitian ini. Kelemahan-kelemahan penelitian sebelumnya tersebut akan diupayakan agar tidak terjadi dalam penelitian ini, sehingga lebih fokus kepada domain yang ada dalam penelitian. Saran dapat disampaikan lebih cermat, rumusan masalah sesuai dengan pemecahan masalah, terdapat keterkaitan yang runut dalam pembahasan, kesesuaian antara tema penelitian dengan rumusan masalah.

\subsection{Pemilihan Model Evaluasi}

Model dalam evaluasi teknologi informasi yang paling sering digunakan adalah model COBIT karena COBIT memiliki cakupan yang sangat luas.COBIT memiliki cakupan 4 domain tetapi belum tentu semua organisasi memiliki atau mencakup keseluruhan proses-proses tersebut. Domain yang akan diteliti hanya bagian DS.11, DS.12 dan ME.1. Karena berdasarkan peneltian sebelumnya domain DS.11 berkaitan dengan Mendefinisikan dan Mengelola tingkat layanan, Ds.12 berkaitan dengan Mengelola lingkungan fisik, dan domain ME.1 berkaitan dengan Mengawasi dan mengevaluasi kinerja TI. Ketiga sub domain ini dimaksudkan agar supaya mendapatkan rekomendasi tentang seberapa besar pengendalian infrastruktur TI dan proses TI pada STMIK Dian Cipta Cendikia Kotabumi serta mengetahui tingkat maturity proses pada STMIK Dian Cipta Cendikia Kotabumi. 


\subsection{Kuesioner}

Kuesioner yang akan digunakan untuk pengumpulan data dibuat berdasarkan variabel variabel yang sudah dibuat berdasarkan acuan dari domain Delivery and Support dan Monitoring and Evaluate pada COBIT 4.1 yang bertujuan untuk mengetahui kepuasan dari para pengguna yaitu Mahasiswa/I, dosen dan karyawan/staff STMIK Dian Cipta Cendikia Kotabumi tentang segala sesuatu yang berhubungan dengan layanan TI yang saat ini sudah berjalan di lingkungan STMIK Dian Cipta Cendikia Kotabumi.

Desain kuesioner yang dibuat dibagi menjadi 3 bagian, yang pertama untuk mengetahui seberapa besar pengendalian proses TI, yang kedua untuk mengetahui seberapa besar pengendalian infrastruktur TI dan ketiga untuk mengetahui tingkat Mengawasi dan mengevaluasi kinerja TI pada STMIK Dian Cipta Cendikia Kotabumi. Serta desain kuesioner yang dibuat menggunakan 6 skala yaitu : sangat buruk, buruk, cenderung buruk, cukup, baik dan sangat baik.

Daftar pertanyaan yang sudah dibuat sebagai desain kuesioner kepada para Mahasiswa/I, dosen dan karyawan/staff STMIK Dian Cipta Cendikia Kotabumi dapat dilihat pada Tabel 4.3 tentang Desain Kuesioner sesuai dengan Indikator COBIT 4.1.

Tabel 4.1. kuesioner DS11

\begin{tabular}{|c|c|c|c|c|c|c|c|}
\hline \multicolumn{8}{|c|}{ Pengendalian Infrastrktur TI } \\
\hline \multirow{2}{*}{\multicolumn{2}{|c|}{ Pernyataan }} & \multicolumn{6}{|c|}{ Tanggapan } \\
\hline & & $\mathbf{1}$ & 2 & 3 & 4 & 5 & 6 \\
\hline 1 & $\begin{array}{l}\text { Bagaimanakah } \\
\text { Layanan } \\
\text { TI(internet, SIM, } \\
\text { dll }) ?\end{array}$ & & & & & & \\
\hline 2 & $\begin{array}{l}\text { Menurut anda, } \\
\text { pihak pengelola } \\
\text { sangat baik dalam } \\
\text { memberikan } \\
\text { informasi tentang } \\
\text { layanan TI? }\end{array}$ & & & & & & \\
\hline 3 & $\begin{array}{l}\text { Bagaimana } \\
\text { Kecapatan dalam } \\
\text { meng akses layanan } \\
\text { TI? }\end{array}$ & & & & & & \\
\hline 4 & $\begin{array}{l}\text { Dengan adanya } \\
\text { layanan yang saat } \\
\text { ini berjalan, } \\
\text { memudahkan } \\
\text { dalam mendapatkan } \\
\text { yang anda inginkan } \\
\text { ? }\end{array}$ & & & & & & \\
\hline
\end{tabular}

Tabel 4.2. kuesioner DS12

\begin{tabular}{|c|c|c|c|c|c|c|c|}
\hline \multicolumn{8}{|c|}{ PENGENDALIAN PROSES TI } \\
\hline \multirow{2}{*}{\multicolumn{2}{|c|}{ Pernyataan }} & \multicolumn{6}{|c|}{ Tanggapan } \\
\hline & & 1 & 2 & 3 & 4 & 5 & 6 \\
\hline 1 & $\begin{array}{l}\text { Penyampaian } \\
\text { penanganan } \\
\text { keluahan sangat } \\
\text { mudah dimengerti } \\
\text { ? }\end{array}$ & & & & & & \\
\hline 2 & $\begin{array}{l}\text { Saat anda } \\
\text { melaporkan } \\
\text { keluahan, pihak } \\
\text { pengelola } \\
\text { melayani anda } \\
\text { dengan baik? }\end{array}$ & & & & & & \\
\hline 3 & $\begin{array}{l}\text { Saat } \\
\text { kesalahan derjadi } \\
\text { layanan, dam } \\
\text { mendapatkan } \\
\text { prosedur yang } \\
\text { tepat } \\
\text { pengelola? }\end{array}$ & & & & & & \\
\hline 4 & $\begin{array}{l}\text { Menurut anda, } \\
\text { pihak pengelola } \\
\text { cepat tanggap } \\
\text { apabila terjadi } \\
\text { gangguan pada } \\
\text { layanan TI? }\end{array}$ & & & & & & \\
\hline 5 & $\begin{array}{l}\text { Menurut anda, } \\
\text { pihak pengelola } \\
\text { selalu } \\
\text { memperbaharui } \\
\text { layanan TI } \\
\text { menjadi lebih } \\
\text { baik setiap } \\
\text { mendapatkan } \\
\text { keluhan dari anda } \\
\text { ? }\end{array}$ & & & & & & \\
\hline
\end{tabular}

Tabel 4.3. kuesioner ME01

\begin{tabular}{|c|c|c|c|c|c|c|c|}
\hline \multicolumn{8}{|c|}{$\begin{array}{l}\text { Pengawasan } \\
\text { PROSES TI }\end{array}$} \\
\hline \multirow{2}{*}{\multicolumn{2}{|c|}{ Pernyataan }} & \multicolumn{6}{|c|}{ Tanggapan } \\
\hline & & & 2 & 3 & 4 & 5 & 6 \\
\hline 1 & $\begin{array}{l}\text { Sejauh mana tingkat } \\
\text { kesadaran } \\
\text { perusahaan sampai } \\
\text { saat ini terhadap } \\
\text { pemantauan dan } \\
\text { pengevaluasian } \\
\text { kinerja TI? }\end{array}$ & & & & & & \\
\hline 2 & $\begin{array}{l}\text { Sejauh mana tingkat } \\
\text { penerapan } \\
\text { pemantauan dan } \\
\text { pengevaluasian } \\
\text { kenerja TI? }\end{array}$ & & & & & & \\
\hline
\end{tabular}




\begin{tabular}{|c|c|}
\hline 3 & $\begin{array}{l}\text { Sejauh mana } \\
\text { penggunaan tool } \\
\text { dalam pemantauan } \\
\text { dan pengevaluasian } \\
\text { kenerja TI? }\end{array}$ \\
\hline 4 & $\begin{array}{lr}\text { Sejauh mana } \\
\text { pengembangan } \\
\text { keterampilan dan } \\
\text { keahlian SDM dalam } \\
\text { bentuk pelatihan } \\
\text { dilakukan guna } \\
\text { mendukung } \\
\text { pemantauan dan } \\
\text { pengevaluasian } \\
\text { kenerja TI? }\end{array}$ \\
\hline
\end{tabular}

\subsection{Hasil Kuesioner}

Setelah mendapatkan hasil kuesioner maka langkah selanjutnya menganalisa maturity level sehingga didapatkan hasil yaitu DS.11 bernilai 3,85 defined process, DS.12 Bernilai 4 Managed and measurable. dan ME.1 Bernilai 4 Managed and measurable.

Table 4.4 Rata - rata hasil kuesioner

\begin{tabular}{|c|c|c|c|}
\hline Responden & $\begin{array}{c}\text { Pengendalia } \\
n \\
\text { Infrastrukt } \\
\text { ur TI }\end{array}$ & $\begin{array}{l}\text { Pengendali } \\
\text { an Proses } \\
\text { TI }\end{array}$ & $\begin{array}{c}\text { Pengawa } \\
\text { san \& } \\
\text { Evaluasi } \\
\text { Proses Tl }\end{array}$ \\
\hline 1 & 3,75 & 4 & 4,5 \\
\hline 2 & 4 & 4,4 & 5 \\
\hline 3 & 4 & 4 & 3,75 \\
\hline 4 & 4,5 & 4,4 & 5 \\
\hline 5 & 3,75 & 4,2 & 4,25 \\
\hline 6 & 5 & 5 & 5 \\
\hline 7 & 5 & 5 & 5 \\
\hline 8 & 5 & 5 & 5 \\
\hline 9 & 5 & 5 & 5 \\
\hline 10 & 5 & 5 & 5 \\
\hline 11 & 3 & 3,4 & 3,5 \\
\hline 12 & 2,5 & 3,4 & 3,75 \\
\hline 13 & 3,25 & 4 & 3,75 \\
\hline 14 & 3,5 & 3,6 & 3,25 \\
\hline 15 & 4,25 & 4,2 & 3,75 \\
\hline 16 & 2 & 2 & 2,25 \\
\hline 17 & 5,5 & 5 & 5 \\
\hline 18 & 5 & 4,8 & 5 \\
\hline 19 & 4,25 & 4,2 & 4 \\
\hline 20 & 6 & 5,4 & 4 \\
\hline 21 & 3,5 & 4,2 & 4 \\
\hline 22 & 4 & 4,4 & 4,5 \\
\hline 23 & 2,25 & 2,4 & 3,75 \\
\hline 24 & 2,75 & 3,8 & 4,25 \\
\hline 25 & 4 & 4,2 & 4 \\
\hline 26 & 2 & 2,2 & 2,25 \\
\hline 27 & 4,25 & 4,4 & 4 \\
\hline 28 & 2,5 & 2,4 & 1,5 \\
\hline 29 & 1 & 1,4 & 2,25 \\
\hline 30 & 5 & 4,2 & 4 \\
\hline 31 & 4,75 & 4,4 & 5 \\
\hline 32 & 5,25 & 5 & 5 \\
\hline
\end{tabular}

\begin{tabular}{|c|c|c|c|}
\hline 33 & 3,75 & 4 & 4 \\
\hline 34 & 1 & 1,2 & 1 \\
\hline 35 & 2,25 & 2,4 & 3 \\
\hline 36 & 3,25 & 3,8 & 3,75 \\
\hline 37 & 3 & 3,6 & 3,75 \\
\hline 38 & 3,5 & 4,6 & 3,75 \\
\hline 39 & 4,75 & 5 & 4,25 \\
\hline 40 & 2,5 & 3,4 & 4,25 \\
\hline 41 & 2,75 & 3,8 & 3,5 \\
\hline 42 & 4,5 & 5 & 4,5 \\
\hline 43 & 4,5 & 4,4 & 4 \\
\hline 44 & 5,25 & 4,6 & 5,25 \\
\hline 45 & 3,5 & 3,4 & 3,25 \\
\hline 46 & 3,25 & 3,2 & 4,25 \\
\hline 47 & 4,5 & 5,4 & 4,75 \\
\hline 48 & 4,5 & 4,4 & 4,5 \\
\hline 49 & 5,25 & 5 & 5,5 \\
\hline 50 & 5 & 5 & 4,5 \\
\hline \hline Index & $\mathbf{3 , 8 5}$ & $\mathbf{4 , 0 2 4}$ & $\mathbf{4 , 0 4}$ \\
Rata 2 & & & \\
\hline
\end{tabular}

4.6 Analisa Hasil Kuesioner

Berdasarkan data hasil survey kuesioner terhadap staff, dosen dan mahasiswa STMIK Dian Cipta Cendikia Kotabumi, analisis yang dilakukan pada tahap ini adalah analisis untuk menilai tingkat kematangan Infrastruktur dan Proses TI untuk domain DS11, DS12 dan domain ME saat ini (as-is). Penilaian terhadap masing-masing domain untuk mengetahui tingkat kematangan masing-masing domain. Dengan hasil kuesioner masing-masing domain sebagai berikut:

Table 4.11 hasil kuesioner pengendalian Infrastrktur TI

\begin{tabular}{|l|c|}
\hline \multicolumn{1}{|c|}{ Pernyataan ISI } & Level \\
\hline Bagaimanakah Layanan TI(internet, SIM, dll)? & 3,7 \\
\hline $\begin{array}{l}\text { Menurut anda, pihak pengelola sangat baik } \\
\text { dalam memberikan informasi tentang layanan } \\
\text { TI ? }\end{array}$ & 4 \\
\hline $\begin{array}{l}\text { Bagaimana Kecapatan dalam meng akses } \\
\text { layanan TI? }\end{array}$ & 3,7 \\
\hline $\begin{array}{l}\text { Dengan adanya layanan yang saat ini berjalan, } \\
\text { memudahkan dalam mendapatkan yang anda } \\
\text { inginkan? }\end{array}$ & 4 \\
\hline \multicolumn{1}{|c|}{ rata-rata index } & 3,85 \\
\hline
\end{tabular}

Berdasarkan hasil kuesioner didapatkan bahwa untuk domain DS11 pengendalian infrastruktur TI pada STMIK Dian Cipta Cendikia Kotabumi bernilai 3,85 yang menunjukkan bahwa pengendalian proses TI cukup baik.

Table 4.12 hasil kuesioner Pengendalian Proses TI 


\begin{tabular}{|c|c|}
\hline Pernyataan ISI & Level \\
\hline $\begin{array}{l}\text { Penyampaian penanganan keluahan sangat } \\
\text { mudah dimengerti ? }\end{array}$ & 3,8 \\
\hline $\begin{array}{l}\text { Saat anda melaporkan keluahan, pihak } \\
\text { pengelola melayani anda dengan baik? }\end{array}$ & 4,1 \\
\hline $\begin{array}{l}\text { Saat terjadi kesalahan dalam layanan, anda } \\
\text { mendapatkan prosedur yang tepat dari } \\
\text { pengelola? }\end{array}$ & 4,0 \\
\hline $\begin{array}{l}\text { Menurut anda, pihak pengelola cepat tanggap } \\
\text { apabila terjadi gangguan pada layanan TI? }\end{array}$ & 4,2 \\
\hline $\begin{array}{l}\text { Menurut anda, pihak pengelola selalu } \\
\text { memperbaharui layanan TI menjadi lebih baik } \\
\text { setiap mendapatkan keluhan dari anda? }\end{array}$ & 3,9 \\
\hline rata-rata index & 4 \\
\hline
\end{tabular}

Berdasarkan hasil kuesioner didapatkan bahwa untuk domain DS12 pengendalian proses TI pada STMIK Dian Cipta Cendikia Kotabumi bernilai 4 yang menunjukkan bahwa pengendalian proses TI cukup baik.

Table 4.13 hasil kuesioner evaluasi dan pemantauan proses TI

\begin{tabular}{|l|c|}
\hline \multicolumn{1}{|c|}{ Pernyataan ISI } & Level \\
\hline $\begin{array}{l}\text { Sejauh mana tingkat kesadaran perusahaan } \\
\text { sampai saat ini terhadap pemantauan dan } \\
\text { pengevaluasian kinerja TI ? }\end{array}$ & 3,8 \\
\hline $\begin{array}{l}\text { Sejauh mana tingkat penerapan } \\
\text { pemantauan dan pengevaluasian kenerja } \\
\text { TI? }\end{array}$ & 4,0 \\
\hline $\begin{array}{l}\text { Sejauh mana penggunaan tool dalam } \\
\text { pemantauan dan pengevaluasian kenerja TI } \\
\text { ? }\end{array}$ & 4,1 \\
\hline $\begin{array}{l}\text { Sejauh mana pengembangan keterampilan } \\
\text { dan keahlian SDM dalam bentuk pelatihan } \\
\text { dilakukan guna mendukung pemantauan } \\
\text { dan pengevaluasian kenerja TI? }\end{array}$ & 4,2 \\
\hline \multicolumn{1}{|c|}{ rata-rata index } & 4,03 \\
\hline
\end{tabular}

Berdasarkan hasil kuesioner didapatkan bahwa untuk domain ME01 tingkat maturity proses TI pada STMIK Dian Cipta Cendikia Kotabumi bernilai 4,3 yang menunjukkan bahwa tingkat maturity proses TI cukup baik

\subsection{Perhitungan Maturity Level}

Analisis yang diambil untuk tingkat kematangan yang diharapakan, meliputi proses DS11, DS12, dan ME1. Maturity level meliputi data sekarang atau data menurut nilai index dari data table 4.4.5 , skala adalah level maturity yang ditetapkan, target adalah level maturity yang diharapkan, dan GAP adalah selisih antara target yang diharapkan dengan index sekarang.

Tabel 4.14 Perhitunga Maturity Level pada Domain DS1

\begin{tabular}{|c|c|c|c|}
\hline Pernyataan ISI & Level & Target & GAP \\
\hline $\begin{array}{l}\text { Bagaimanakah } \\
\text { Layanan } \\
\text { TI(internet, SIM, } \\
\text { dll)? }\end{array}$ & 3,7 & 5 & 2,3 \\
\hline \begin{tabular}{lr}
\multicolumn{2}{l}{ Menurut anda, pihak } \\
pengelola sangat \\
baik & dalam \\
memberikan & \\
informasi tentang \\
layanan TI?
\end{tabular} & 4 & 5 & 1 \\
\hline $\begin{array}{l}\text { Bagaimana } \\
\text { Kecepatan dalam } \\
\text { meng akses layanan } \\
\text { TI? }\end{array}$ & 3,7 & 5 & 2,3 \\
\hline $\begin{array}{l}\text { Dengan adanya } \\
\text { layanan yang saat ini } \\
\text { berjalan, } \\
\text { memudahkan dalam } \\
\text { mendapatkan yang } \\
\text { anda inginkan? }\end{array}$ & 4 & 5 & 1 \\
\hline rata-rata index & 3,85 & 5 & 1,65 \\
\hline
\end{tabular}

Berdasarkan analisa tingkat kematangan maturity level pada domain DS11 didapatkan bahwa tingkat kematangan berada pada level 4-Defined

Tabel 4.15 Perhitunga Maturity Level pada Domain DS12

\begin{tabular}{|l|c|c|c|}
\hline \multicolumn{1}{|c|}{ Pernyataan ISI } & Level & Target & GAP \\
\hline $\begin{array}{l}\text { Penyampaian } \\
\text { penanganan anda } \\
\text { keluahan sangat } \\
\text { mudah dimengerti ? }\end{array}$ & 3,8 & 5 & 1,2 \\
\hline $\begin{array}{l}\text { Saat andaporkan terjadi } \\
\text { melapok } \\
\text { keluahan, pihak } \\
\text { pengelola melayani } \\
\text { anda dengan baik? }\end{array}$ & 4,1 & 5 & 0,9 \\
\hline $\begin{array}{l}\text { Saat } \\
\text { kesalahan dalam } \\
\text { layanan, } \\
\text { mendapatkan setiap } \\
\text { prosedur yang tepat } \\
\text { dari pengelola? }\end{array}$ & 4,0 & 5 & 1 \\
\hline $\begin{array}{l}\text { Menurut anda, pihak } \\
\text { pengelola cepat } \\
\text { tanggap apabila } \\
\text { terjadi gangguan } \\
\text { pada layanan TI? }\end{array}$ & 4,2 & 5 & 0,8 \\
\hline $\begin{array}{l}\text { Menurut anda, pihak } \\
\text { pengelola selalu } \\
\text { memperbaharui } \\
\text { layanan TI menjadi } \\
\text { lebih baik satkan } \\
\text { mendapatkan } \\
\text { keluhan dari anda? }\end{array}$ & 3,9 & 5 & 4,1 \\
\hline rata-rata index & 4 & 5 & 1,6 \\
\hline
\end{tabular}

Berdasarkan analisa tingkat kematangan maturity level pada domain DS12 didapatkan bahwa tingkat kematangan berada pada level 4 Defined 
Tabel 4.16 Perhitunga Maturity Level pada Domain ME01

\begin{tabular}{|l|c|c|c|}
\hline \multicolumn{1}{|c|}{ Pernyataan ISI } & Level & Target & GAP \\
\hline $\begin{array}{l}\text { Sejauh mana tingkat } \\
\text { kesadaran perusahaan } \\
\text { sampai saat ini terhadap } \\
\text { pemantauan dan } \\
\text { pengevaluasian kinerja TI ? }\end{array}$ & 3,8 & 5 & 1,2 \\
\hline $\begin{array}{l}\text { Sejauh mana tingkat } \\
\text { penerapan pemantauan dan } \\
\text { pengevaluasian kenerja TI? }\end{array}$ & 4,0 & 5 & 1 \\
\hline $\begin{array}{l}\text { Sejauh mana penggunaan } \\
\text { tool dalam pemantauan dan } \\
\text { pengevaluasian kenerja TI } \\
\text { ? mana }\end{array}$ & 4,1 & 5 & 0,9 \\
\hline $\begin{array}{l}\text { Sejauh } \\
\text { pengembangan } \\
\text { keterampilan dan keahlian } \\
\text { SDM dalam bentuk } \\
\text { pelatihan dilakukan guna } \\
\text { mendukung pemantauan } \\
\text { dan pengevaluasian kenerja } \\
\text { TI? }\end{array}$ & 4,2 & 5 & 0,8 \\
\hline rata-rata index & 4,03 & 5 & 0,98 \\
\hline
\end{tabular}

4.8 Rekomendasi

a) Rekomendasi Perbaikan Proses DS11 Pengendalian Proses TI

DS 11 Mengelola Data, bahwa pengelolaan data (proses input, pemrosesan dan output) diperlukan untuk menjamin integritas, keakuratan dan validitas data.

Temuan :

STMIK Dian Cipta Cendikia kotabumi memiliki pengolahan data, tapi tidak terstruktur dan diformalkan

Rekomendasi untuk menuju ke tingkat 4 Managed and Measurable

a. Backing up data dan menguji restorasi

b. Mengelola penyimpanan data ditempat dan diluar lokasi

c. Membuat pedoman dan prosedur pengelolaan data, pedoman tersebut disosialisasikan secara luas di Organisasi, dan antar unit saling berbagi

d. Mengharuskan pelatihan formal khusus bagi anggota staf pengelola data

b) Rekomendasi Perbaikan Proses DS12 Penendalian Infrastruktur TI

I.1.1 DS 12 Mengelola Lingkungan Fisik, meliputi mendefinisikan persyaratan lokasi fisik, memilih fasilitas yang tepat, dan rancangan proses-proses yang efektif untuk memonitor faktor lingkungan dan mengelola akses fisik. Pengelolaan lingkungan fisik yang efektif dapat mengurangi gangguan bisnis dari kerusakan peralatan komputer serta personelnya.

Temuan :

Tidak memiliki langkah pengamanan fisik

I.1.2 Rekomendasi untuk menuju ke tingkat 4 Managed and Measurable

Megelola lingkungan fisik, dengan memberikan dan memlihara lingkungan fisik yang sesuai, untuk menjaga aset TI dari akses, kerusakan ataupencurian

a) Melaksanakan tindakan pengamanan fisik

b) Memilih dan mengelola fasilitas

c) Memahami sepenuhnya kebutuhan untuk memelihara lingkungan komputasi yang terkontrol, dengan membentuk unit tertentu yang bertugas mengelola fisik TI dan alokasi anggaran yang cukup.

d) Melatih anggota staf untuk mengatasi situasi darurat, serta pelatihan pelaksanaan mengelola lingkungan fisik TI secara sehat dan aman.

e) Rekomendasi Perbaikan Proses ME1 Tingkat Maturity Proses TI

ME01 Mengawasi dan Mengevaluasi Kinerja TI, bahwa tujuan pengawasan dan evaluasi supaya kinerja TI dilakukan agar lebih efektif. Proses ini mencakup penetapan indikator kinerja, sistematis, pelaporan berkala dan tindakan terhadap penyimpangan.

Temuan

STMIK Dian Cipta Cendikia Kotabumi tidak memiliki pengendalian TI internal, tidak ada evaluasi TI secara formal yang dilakukan

Rekomendasi untuk menuju ke tingkat 4 Managed and Measurable

Memantau dan mengevaluasi kinerja TI, dengan pemantaua dan pelaporan metrik proses, serta mengidentifikasi dan menerapkan peningkatan kinerja

a. Mengumpulkan dan menerjemahkan laporan kenerja proses kedalam laporan manajemen

b. Meninjau kenerja terhadap target yang disepakati dan menginisiasi tindakan perbaikan yang diperlukan

c. Membuat sistem pelaporan hasil pengawasan kinerja TI secara formal, terstandarisasi dan normalisasi. 
Mengintegrasikan peralatan yang otomatis dan dimanfaatkan oleh STMIK Dian Cipta Cendikia Kotabumi untuk mengumpulkan informasi operasional pada aplikasi, dan mengawasi sistem dan kinerja TI.

\section{KESIMPULAN}

5.1.Kesimpulan

Implementasi tata kelola teknologi informasi di STMIK DCC Kotabumi khususnya evaluasi tingkat kematangan domain DS dan domain ME, berdasarkan hasil kuesioner didaptkan bahwa tingkat kematangan untuk domain DS11 pengendalian infrastruktur TI pada STMIK Dian Cipta Cendikia Kotabumi bernilai 3,85 yang menunjukkan bahwa pengendalian proses TI cukup baik, dan untuk domain DS12 pengendalian proses TI pada STMIK Dian Cipta Cendikia Kotabumi bernilai 4 yang menunjukkan bahwa pengendalian proses TI cukup baik, dan untuk domain ME01 tingkat tingkat Pengawawan dan evaluasi proses TI pada STMIK Dian Cipta Cendikia Kotabumi bernilai 4,3 yang menunjukkan bahwa tingkat maturity proses TI cukup baik.

Kemudian Berdasarkan analisa tingkat kematangan maturity level pada domain DS11 didapatkan bahwa tingkat kematangan berada pada level 4-Defined level, untuk domain DS12 didapatkan bahwa tingkat kematangan berada pada level 4 - Defined leve, dan pada domain ME01 didapatkan bahwa tingkat kematangan berada pada Level: 4 - Defined level

\section{6. .SARAN}

1. Mendasarkan kepada hasil penelitian didapatkan bahwa kerangka kerja Cobit 4.1 dengan domain DS dan ME ternyata kedua domain dimaksud semuanya bisa diterapkan di STMIK Dian Cipta Cendikia Kotabumi. Domain DS dan domain ME bisa dan layak digunakan sebagai kerangka kerja Cobit 4.1, walau belum diterapkan sepenuhnya. Maka sebaiknya STMIK Dian Cipta Cendikia Kotabumi dapat lebih meningkatkan tata kelola teknologi nya dengan lebih baik lagi.

DAFTAR PUSTAKA

[1] PUSTAKA BUKU

[1] Gondodiyoto, Sanyoto. "Audit sistem informasi+ pendekatan CobIT." Jakarta: Mitra Wacana Media (2007).

[2] ITGI, IGI. "COBIT 4.1." Framework Control Objective Management Guidelines Maturity Model (2007).
[1] Pustaka Majalah, Jurnal Ilmiah Atau Prosiding

[3] Jusuf, Heni. "IT Governance pada layanan akademik on-line di universitas nasional menggunakan COBIT (control objectives for information and related technology) versi 4.0." Jurnal Fakultas Hukum UII (2009).

[4]Arumana, Arini, Adian Fatchur Rochim, and Ike Pertiwi Windasari. "Analisis Tata Kelola Teknologi Informasi Menggunakan Kerangka Kerja COBIT 4.1 pada Fakultas Teknik Undip." Jurnal Teknologi dan Sistem Komputer 2.2 (2014): 162-169.

[5] Tresyadora, Yesinta Baby, Ssi Usman Sudibyo, And M. Kom. "Analisis Tata Kelola Ti Proses Bisnis (Dss06) Inventory Barang Mesin Fotocopy Pada Pt. Astragraphia Tbk Berdasarkan Framework Cobit 5."

[6] Anas, Akhir Diraja. "Audit Tata kelola Sistem Kepegawaian Dinas Tenaga Kerja dan Transmigrasi Provinsi Sumatera Selatan dengan Kerangka COBIT Versi 5." SKRIPSI MAHASISWA TI SI (2013).

[7] Islamiah, Mega Putri. "Tata kelola teknologi informasi (IT governance) menggunakan framework cobit 5: studi kasus Dewan Kehormatan Penyelenggara Pemilu (DKPP)." (2014).

[8] Winalia, Winalia, Faiza Renaldi, and Asep Id Hadiana. "Pengukuran Tingkat Kematangan Teknologi Informasi menggunakan COBIT 4.1 Pada Universitas Jenderal Achmad Yani." Seminar Nasional Aplikasi Teknologi Informasi 2017. Islamic University of Indonesia, 2017.

[9] Megawati, Megawati, and Fauzi Amrullah. "evaluasi tingkat kematangan teknologi informasi dengan menggunakan model maturity level cobit 4.1 (studi kasus pt. bri cabang bangkinang)." Jurnal Sains dan Teknologi Industri 12.1 (2014): 99-105.

[10] Utomo, Agus Prasetyo, and Novita Mariana. "Analisis Tata Kelola Teknologi Informasi (It Governance) pada Bidang Akademik dengan Cobit Frame Work Studi Kasus 
pada Universitas Stikubank

Semarang." Dinamik 16.2 (2011).

[11] Alit, Ronggo, et al. "Pengukuran Tata Kelola Infrastruktur Teknologi Informasi Berdasarkan Cobit Framework 4. 1 (Studi Kasus Universitas Pembangunan Nasional "Veteran" Jawa Timur)." SCAN-Jurnal Teknologi Informasi dan Komunikasi, 2015 SCAN 10.2 (2015).

[12] Djohan, Agnes. "Penilaian Tingkat Kematangan Strategic Alignment Bisnis Dan Ti Menggunakan Cobit 4.1: Studi Kasus Universitas Xyz." Sesindo 20142014 (2014).

[13] Winardi, Sugeng. "Penggunaan Kerangka Kerja Cobit Untuk Menilai Pengelolaan Teknologi Informasi dan Tingkat Pelayanan (Studi Kasus Pada BMT " $\mathrm{X}$ " Yogyakarta)." Jurnal Teknologi Informasi Respati 7.19 (2017).

[14] Tambotoh, Johan JC, and Rudi Latuperissa. "The Application for Measuring the Maturity Level of Information Technology Governance on Indonesian Government Agencies Using COBIT 4.1 Framework." Intelligent Information Management 6.01 (2014): 12.

[15] Khther, Rasha Adnan, and Marini Othman. "Cobit framework as a guideline of effective it governance in higher education: a review." International Journal of Information Technology Convergence and Services 3.1 (2013): 21.

[16] Darmanto, Yusup, Mohammad Suyanto, and Sudarmawan Sudarmawan. "Analisis Tata Kelola Teknologi Informasi pada Lembaga Kursus dan Pelatihan." Creative Information Technology Journal 1.2 (2014): 102-115.

[17] Janti, Suhar. "Analisis validitas dan reliabilitas dengan skala likert terhadap pengembangan si/ti dalam penentuan pengambilan keputusan penerapan strategic planning pada industri garmen." Prosiding Seminar Nasional Aplikasi Sains \& Teknologi (SNAST). Vol. 15. 2014.. 